\title{
feature Missouri Ozark Plateau Headwaters Diversion engineering feat
}

\author{
Kenneth R. Olson, Lois Wright Morton, and David Speidel
}

$\mathrm{T}$ he Headwaters Diversion, a system of impounding basins, channels, and levees, carries the waters of the eastern Missouri Ozark Plateau hill streams eastward to the Mississippi River south of Cape Girardeau (figure 1). The system consists of three large basins, $78 \mathrm{~km}(50.3$ mi) of channels, and $69 \mathrm{~km}$ (44.7 mi) of levees designed in 1910s by the Little River Drainage District (LRDD) to divert and temporarily store ordinary and flood waters running off 288,000 ha $(720,000 \mathrm{ac})$ of the Francois Mountains and Ozark Plateau uplands (Burns 1919; Engineering Record 1914; LRDD 2012). Today, the Headwaters Diversion helps drain and protect 480,000 ha (1.2 million ac) of agricultural lands in southeast Missouri from internal seasonal flooding and Mississippi River backflow at flood stage (figure 1). It was constructed concurrently with an intricate network of $1,500 \mathrm{~km}$ (957 mi) of ditches, $375 \mathrm{~km}$ (242 mi) of levees, and water detention basins draining thousands of alluvial wetland hectares (acres) in the ancient Mississippi River floodplain running south from the diversion levee $144 \mathrm{~km}(90 \mathrm{mi})$ to the Arkansas border and is the focus of an upcoming article in the March/April 2016 issue of the Journal of Soil and Water Conservation (Olson et al. 2016).

Prior to the construction of the 72 km (45 mi) Headwaters Diversion channel, the Castor and Whitewater rivers and Crooked Creek flowed off the elevated plateaus onto the second bottomlands, with waters pooling in the extensive lowlands and depressions of the historic Big Swamp and into the tributaries of the Little River (Engineering Record 1914). Onethird of this heavily forested alluvial plain was permanently under water, and $70 \%$

Kenneth R. Olson is professor of soil science in the College of Agricultural, Consumer, and Environmental Sciences, University of Illinois, Urbana, Illinois. Lois Wright Morton is professor of sociology in the College of Agriculture and Life Sciences, lowa State University, Ames, lowa. David Speidel is a Soil and Water Conservation Society member, Benton, Missouri. was under water from two to six months during the year, allowing only $15 \%$ of land to be cultivated. During this period, the Little River naturally drained the entire Bootheel region of southeast Missouri into the Arkansas-White-Red River basin. Labeled one of the world's largest land reclamation projects (Joiner 2010), the draining of over 480,000 ha (1.2 million ac) of swampland transformed southeast
Missouri lowlands into a rich agricultural region known for soybeans (Glycine max [L.] Merr.), wheat (Triticum aestivum L.), sorghum (Sorghum biocolor [L.] Moench), rice (Oryza sativa L.), cotton (Gossypium hirsutum L.), peaches (Prunus persica), and watermelons (Citrullus lanatus). Central to the success of this engineering feat was the diversion of water originating in the Ozark Plateau and Francois Mountains

\section{Figure 1}

The Headwaters Diversion Watershed drains Missouri Ozark upland streams southward where they are diverted directly into the Mississippi River south of Cape Girardeau, Missouri, via the diversion channel. Map by Mic Greenberg.

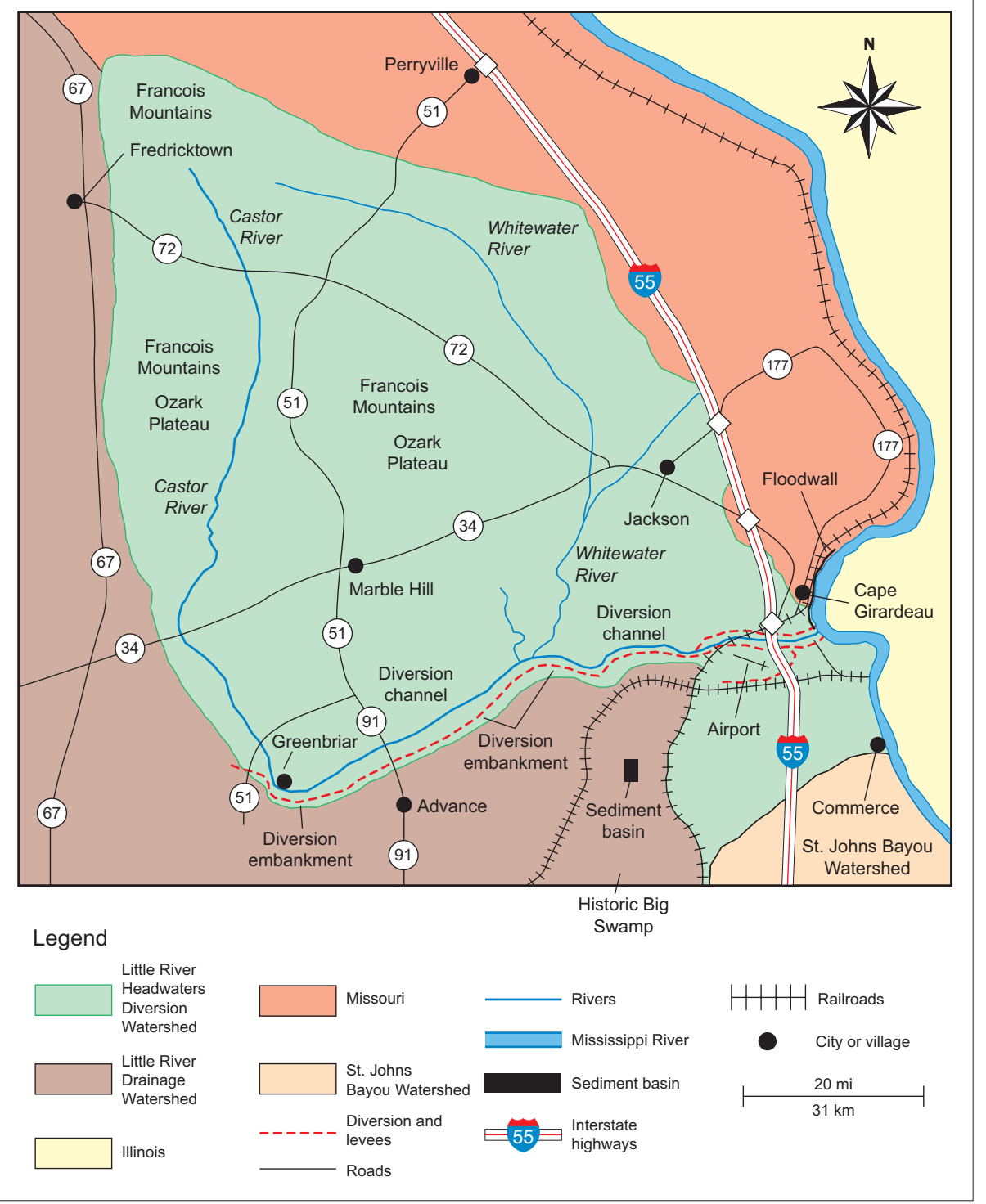


directly into the Mississippi River using a series of leveed channels. The intent of this diversion in the northeastern corner of the LRDD was to isolate the upper basin and prevent overloading of the lower drainage system constructed to drain the low-gradient, slow-moving waters in the historic river floodplain south.

\section{GEOLOGY OF THE HEADWATERS DIVERSION WATERSHED}

The Headwaters Diversion Watershed is triangular in shape with the apex about 16 $\mathrm{km}(10 \mathrm{mi})$ northeast of Fredericktown, Missouri (figure 1). Located in the Missouri Ozark Plateau, the watershed is part of the upland land bridge-the Shawnee and Ozark hills—which connected the southern Appalachians and the Ozark highlands (Ouachita and Francois mountains; figure 2). This land bridge separated the central lowlands to the north and the southern Mississippi lowlands trough, which was submerged by the Coastal Plain Sea for billions of years. The Ozark highlands, Francois Mountains, and the Shawnee uplands were formed by volcanic and intrusive activity about 1.485 billion years ago. By comparison, the Appalachian Mountains were formed about 460 million years ago (Cremeens et al. 2005). Granite and rhyolite, two highly visible igneous rocks found in the Ozarks, were the result of a series of volcanic eruptions and ash flows which melted and cooled pre-existing rocks from the earth's crust. Other igneous rocks made from volcanic magna contain crystallized minerals rich in silicon (Si), aluminum (Al), sodium $(\mathrm{Na})$, potassium $(\mathrm{K})$, calcium $(\mathrm{Ca})$, iron $(\mathrm{Fe})$, and magnesium $(\mathrm{Mg})$ (LeMaitre et al. 2002).

The geological history of the land bridge left a wealth of minerals in the Shawnee uplands in Illinois (figures 2 and 3) and the Francois Mountains of the Ozarks (figure 1). The Ozarks were the center of the Lead Belt in the 1700s and 1800 s, a mining region yielding lead $(\mathrm{Pb})$, Fe, barite $\left(\mathrm{BaSO}_{4}\right)$, zinc $(\mathrm{Zn})$, silver $(\mathrm{Ag})$, manganese $(\mathrm{Mn})$, cobalt $(\mathrm{Co})$, and nickel (Ni) ores. The historic Mine La Motte near Fredericktown, Missouri (in the St. Francis River basin), was the site of $\mathrm{Pb}$ mining activity by the French as early as 1702. The area today accounts for over

\section{Figure 2}

The land bridge in Illinois is connected to the southern Appalachians and the Ozark Plateau. Map by Mic Greenberg.

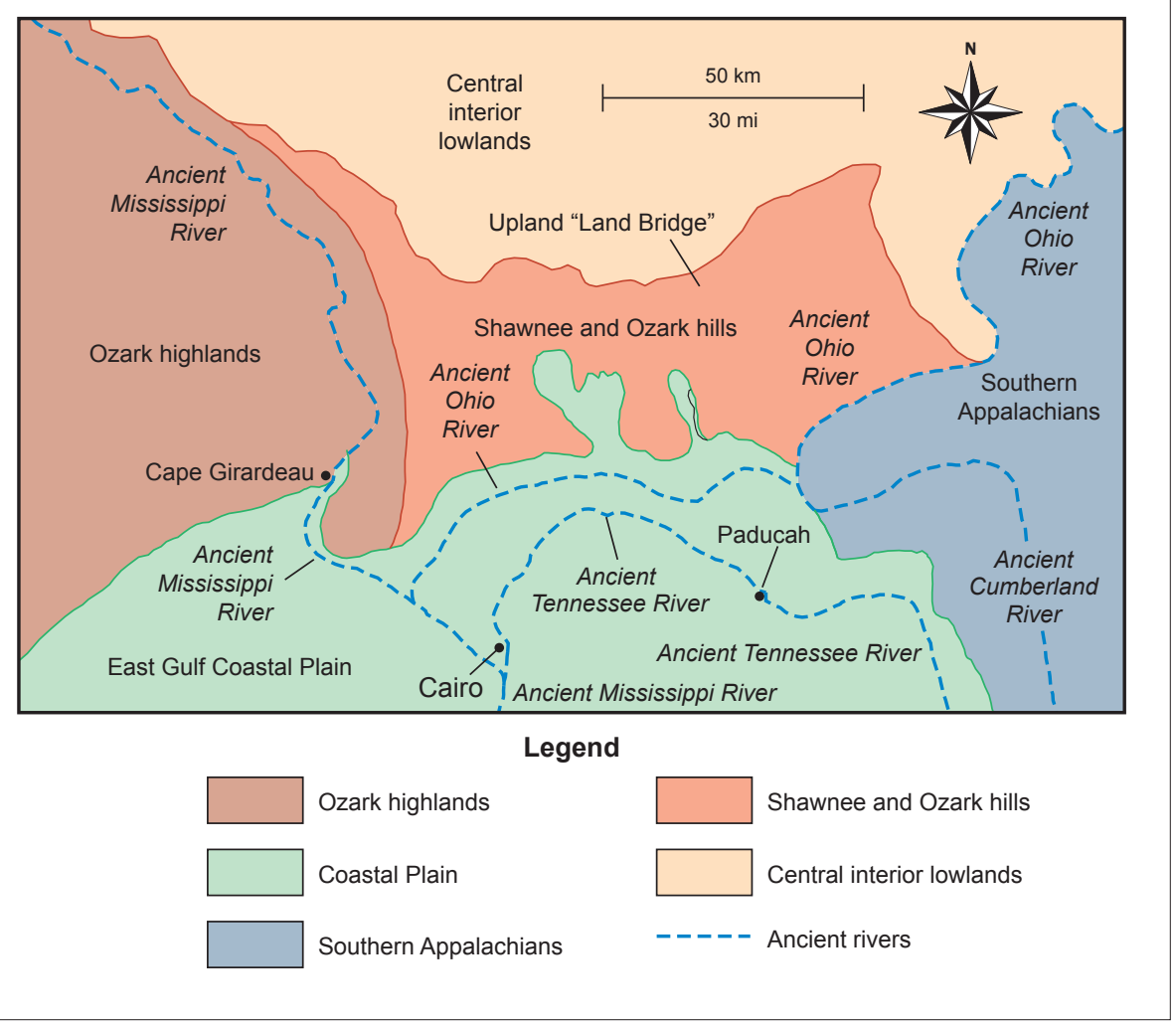

\section{Figure 3}

This Illinois Shawnee upland mining operation in the land bridge between the southern Appalachians and the Ozark highlands continues to be active today.

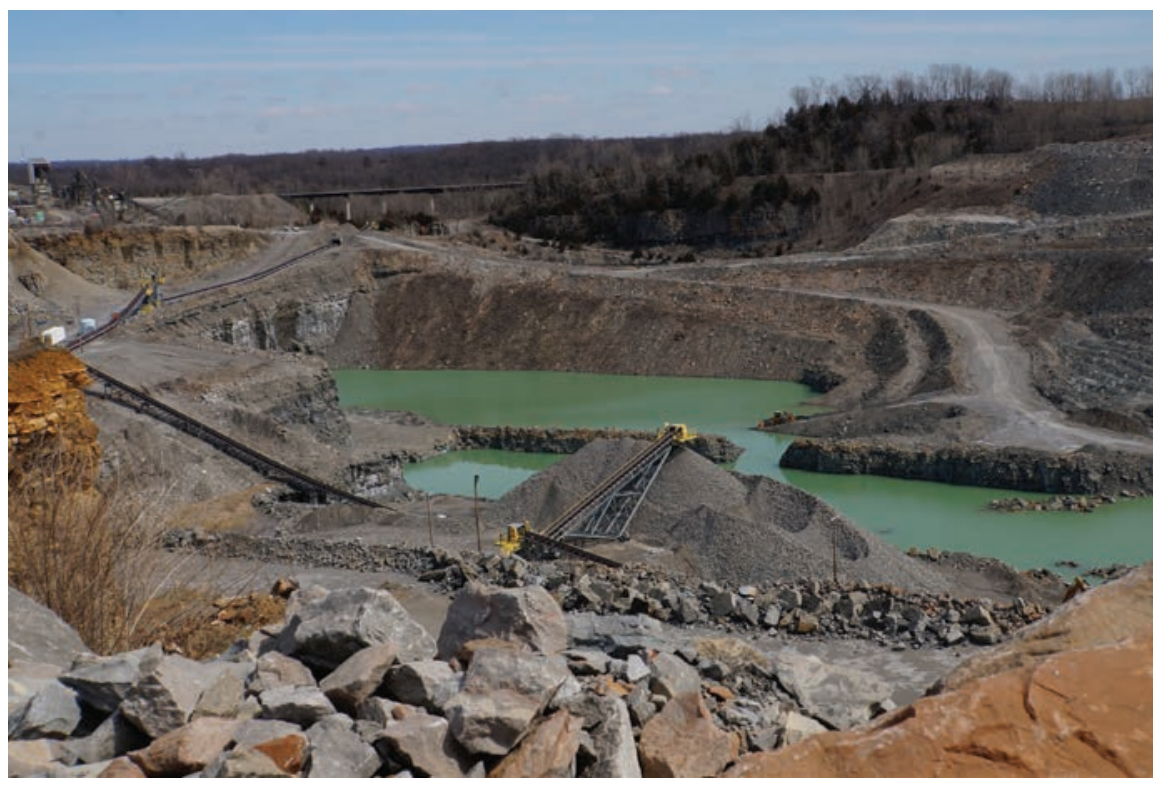




\section{Figure 4}

The headwaters of the Castor River flowing through the Ozark Plateau have the same aqua green color as Shawnee upland lakes created by mining industries.

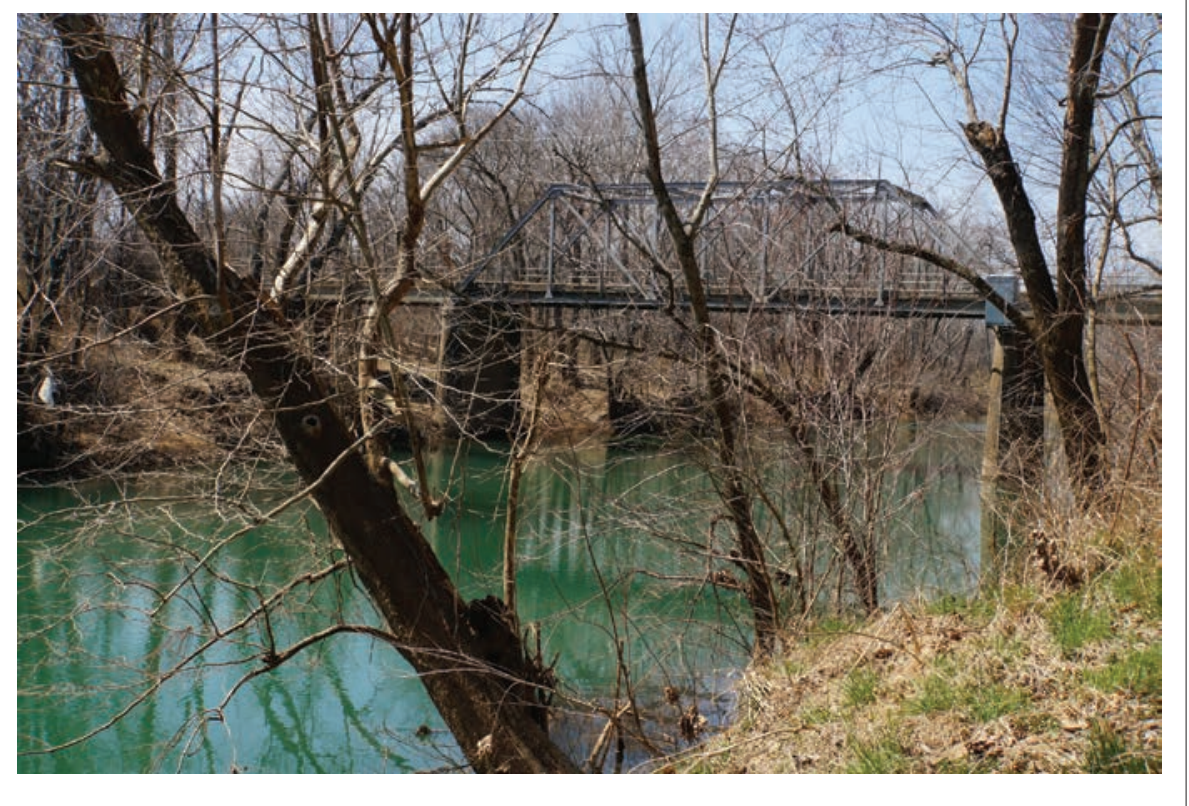

$90 \%$ of the primary $\mathrm{Pb}$ production in the United States. Granite has been commercially quarried since 1869 in the vicinity of Elephant Rocks State Park. The red architectural granite quarried in the area has been used in buildings in St. Louis and other cities and is currently marketed as "Missouri Red" monument stone (Elephant Rocks State Park 2014). Nearby Taum Sauk Mountain is the highest peak in the range and the highest point in the state of Missouri at $540 \mathrm{~m}(1,772 \mathrm{ft})$.

The continental climate of this region produces an average annual precipitation of about 114 to $122 \mathrm{~cm}$ (45 to $48 \mathrm{in}$ ) with warm moist air from the Gulf of Mexico flowing northeast and dropping moisture as it interacts with cold air from Canada. The Ozark Plateau is a rugged landscape of narrow valleys 30 to $910 \mathrm{~m}$ (100 to $3,000 \mathrm{ft}$ ) in width with steep $3: 1$ side slopes and rock-strewn whitewater rivers that are only navigable in or near flood stage conditions (Engineering Record 1914). Today, this is a favorite recreational area for hiking, kayaking, and whitewater paddling. Over time, the Castor (figure 4) and Whitewater rivers in this region have carved through the soft limestone and dolomite surface rocks, leaving exposed pink granite and rhyolite igneous rocks and creating narrow "shut-in" streams with unexpected ledge drops into pools, rocky shoals, and riffles that experienced paddlers use to test their skills (McCord 2014).

Prior to the construction of the diversion channel, the headwaters of the Castor and Whitewater rivers and Crooked Creek were tributaries of the Little River (figure 1), which flowed south and drained much of southeast Missouri (Bootheel) into Arkansas. In the 1910s, the upper portion of the Castor River basin was diverted from its natural channel and now drains into the westernmost basin of the diversion channel, which carries water east directly into the Mississippi River. The disconnected southern portion of the Castor River has become part of the extensive network of channels and ditches of the lower LRDD.

\section{THE FORMATION OF LITTLE RIVER DRAINAGE DISTRICT}

The reddish yellow clay soils of the forested Ozark uplands underlain by impervious hardpan grade into the alluvial lowland soils of the ancient Mississippi River floodplain. These timbered bottomlands of sloughs, bayous, and the slow-moving Little River became of one of the largest tracts of wetlands in the United States drained to create agricultural lands and rural settlements. Much of southeast Missouri was a natural basin that caught runoff water from adjacent uplands, including the Francois Mountains and the Crowley's Ridge. Before the diversion channel and a series of large levees were constructed, floodwaters regularly spilled into the basin and created a swamp that was unsuitable for human settlement. The National Swamp Land Act of 1850 gave the wetlands southwest of Cape Girardeau to the state of Missouri. The state conveyed the land to counties from 1860 to 1890 , and the counties eventually sold the land to private companies and individuals.

It is commonly thought the LRDD was the first attempt to develop the swamplands of southeast Missouri. However, historical records indicate that by 1905 one-half of the basin had been partially reclaimed and assessed by earlier organized drainage districts. These prior drainage projects became the building blocks for unifying the financing, governing, and engineering efforts under the LRDD. Due to the difficulties of draining these swamplands, it took almost 50 years to develop the necessary laws, business models, and engineering techniques needed to create a successful drainage district model. Engineering innovations, willing investors, and men and women with perseverance settling the region were important factors in building the roads, rails, and bridges that became the basic infrastructure for draining the region.

In 1905, a meeting of large landowners and local leaders was held in Cape Girardeau, Missouri, to create the LRDD, which included parts of seven Missouri counties. Two years later, the state circuit court approved the LRDD as a not-forprofit organization. The district was given the ability to set benefit tax assessment levels. Chief Engineer Otto Kochtitzky and the five-member LRDD board of supervisors had a vision for constructing an east-west channel across the top of the drainage system (Kochtitzky 1931) (figure 2) and a series of smaller parallel ditches running north to south to the Arkansas border that would drain the great Missouri wetlands (Olson et al. 2016). Isham Randolph of Chicago, 
an eminent civil engineer, was employed as a consulting engineer in developing the LRDD drainage plan (LRDD Staff 1909). The Headwaters Diversion and the lower district ditches drain approximately 120 million L (31 million gal) of water per year directly or indirectly into the Mississippi River.

The Headwaters Diversion levees and channel system was built on land owned by Louis Houck, a prominent civil leader and landowner. In 1910, he was concerned that the land he owned south of Cape Girardeau and his railroad interests would be damaged. He did not want to have to pay a benefit tax assessment to LRDD. Twice Houck fought the LRDD all the way to the US Supreme Court to keep his land from being involved in the LRDD. Both times he lost (Lewis 2012). In 1913, the LRDD financed construction by issuing US\$11.1 million in bonds. The project was paid for by collecting a benefit tax assessment from bottomland landowners of US $\$ 10 \mathrm{ha}^{-1}\left(\mathrm{US} \$ 4 \mathrm{ac}^{-1}\right)$.

\section{CONSTRUCTING THE HEADWATERS DIVERSION SYSTEM}

On November 27, 1912, the LRDD awarded the US $\$ 1.25$ million dollar project to D.C. Stephens Company of Buffalo, New York (Lewis 2012). The contract called for creation of a $47 \mathrm{~km}$ (30 mi) drained channel with an outlet at the Mississippi River just south of Cape Girardeau, Missouri. The channel was to be $30 \mathrm{~m}(100 \mathrm{ft})$ wide and $6 \mathrm{~m}(20 \mathrm{ft})$ deep (figure 5). The project required the clearing of 1,600 ha $(4,000 \mathrm{ac})$ of timber and creation of $62 \mathrm{~km}$ (40 mi) of levees (figure 6) on the south side of the Headwaters Diversion channel. The moving of 6.7 million $\mathrm{m}^{3}$ (8.8 million $\left.\mathrm{yd}^{3}\right)$ of soil made it the largest single contract for earth movement in the world, even larger than the Panama Canal. Headwaters from the Castor River were to be diverted into the new diversion channel starting near the town of Greenbrier in Bollinger County (figure 1).

According to Engineering Record published in 1914, the maximum service the diversion channel was designed to handle was based on the maximum storm discharge simultaneously with flooding in the Mississippi River equal to

\section{Figure 5}

The diversion channel flows east from the Castor River to Mississippi River and outlets south of Cape Girardeau.

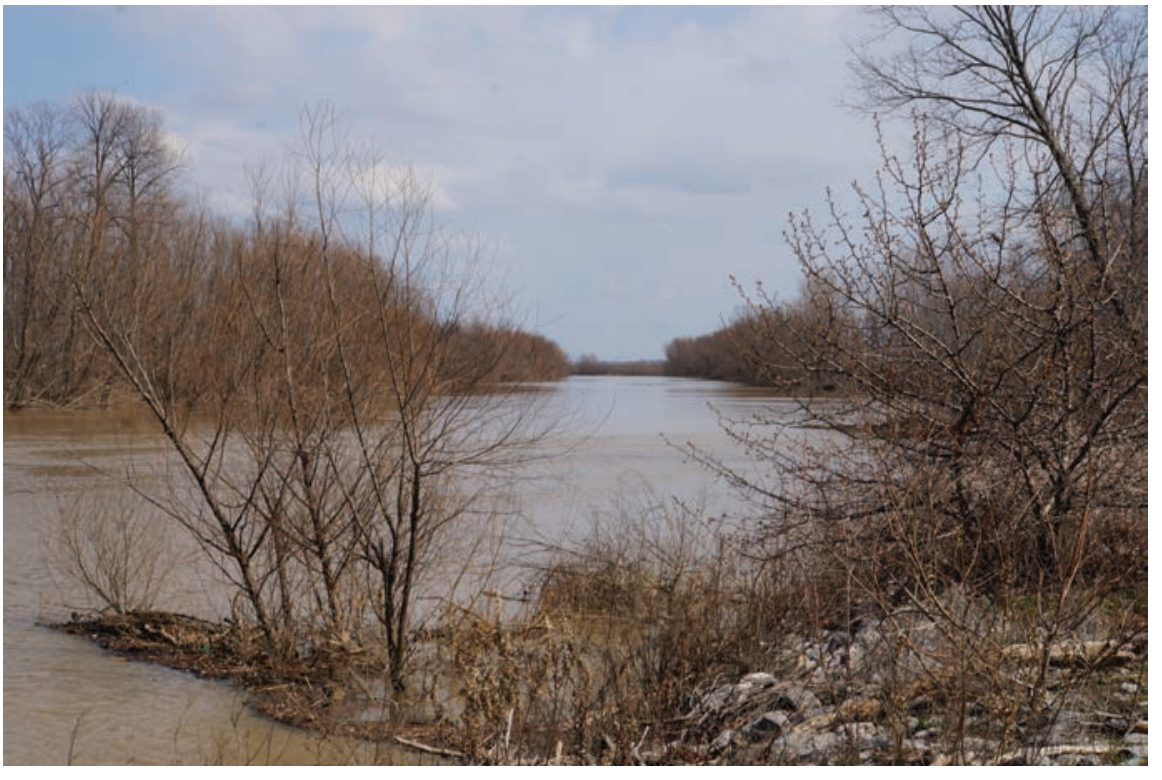

the 1844 height of $3.6 \mathrm{~m}$ (12 ft) out-ofbanks. Engineers based their maximum calculations on precipitation patterns and capacity to handle extreme storm events in the upland region. Prior to 1914, weather stations in the area had recorded extreme rain events 20.8 to $23.8 \mathrm{~cm}(8.3$ to 9.5 in) in 48 hours and 26.3 to 32.5 $\mathrm{cm}$ (10.5 to 13 in) 72 hours. The highest record rainfall was in July of 1905 with $16.1 \mathrm{~cm}$ (6.45 in) on July 20, followed by $2.8 \mathrm{~cm}$ (0.91 in) on July 21.

The original diversion channel consisted of three detention basins (West, Middle, and East), located at points where major headwater streams (Castor, Crooked Creek, and Whitewater) intersected the channel. These basins with the main channel running through them were designed to store excess water-first receiving the flood pulse, then breaking and reducing the crest by holding the water for a short time and slowing the release into the next basin. The "...crest was assumed to enter the West and Middle basins at the same time, resulting in backflow from the Middle to the West basin with no outflow from the latter until 31 hours after the storm began" (Engineering Record 1914). The Crooked Creek (between the two basins) hydrograph was placed eight hours back to allow for the crest through the West basin. The headwaters of the Castor River (figure 4) ran directly into the West basin, which extended east about $19 \mathrm{~km}$ (12 mi) and encompassed an area of $40 \mathrm{~km}^{2}$ (15 $\mathrm{mi}^{2}$ ) with capacity to hold 0.14 billion $\mathrm{m}^{3}$ (5 billion $\mathrm{ft}^{3}$ ) of water at an elevation of $111 \mathrm{~m}$ (367 ft). The basin was formed by an earthen levee on the south side running 3.6 to $6.1 \mathrm{~m}$ (12 to $20 \mathrm{ft})$ high, with a (3.6 m) $12 \mathrm{ft}$ crown and 1:2 side slopes, and the Ozark foothills on the north. The earthen levee extended the diversion channel 19 $\mathrm{km}(12 \mathrm{mi})$ to the west of the diversion embankment and channel. Flood crests passing through the West basin were to be delayed about 8 hours with peak discharge from where the Castor River entered at its outlet.

Crooked Creek and Whitewater River flowed into the Middle basin and made up the main diversion channel. This basin was bounded on the south by elevated ridges and on the north by the uplands. It had a maximum capacity of more than 0.03 billion $\mathrm{m}^{3}\left(1\right.$ billion $\left.\mathrm{ft}^{3}\right)$ and covered an area of $11.7 \mathrm{~km}^{2}\left(4.5 \mathrm{mi}^{2}\right)$. As the diversion channel flowed east into the Mississippi River floodplain, the East basin was leveed on both sides with embankments 4.8 to $6.1 \mathrm{~m}$ (16 to $20 \mathrm{ft}$ ). The north embankment east of the East basin was designed

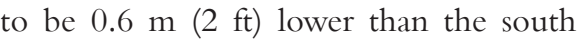




\section{Figure 6}

The diversion embankment protects agricultural bottomlands from the Missouri Ozarks upland stream runoff and Mississippi River backwater at flood stage.

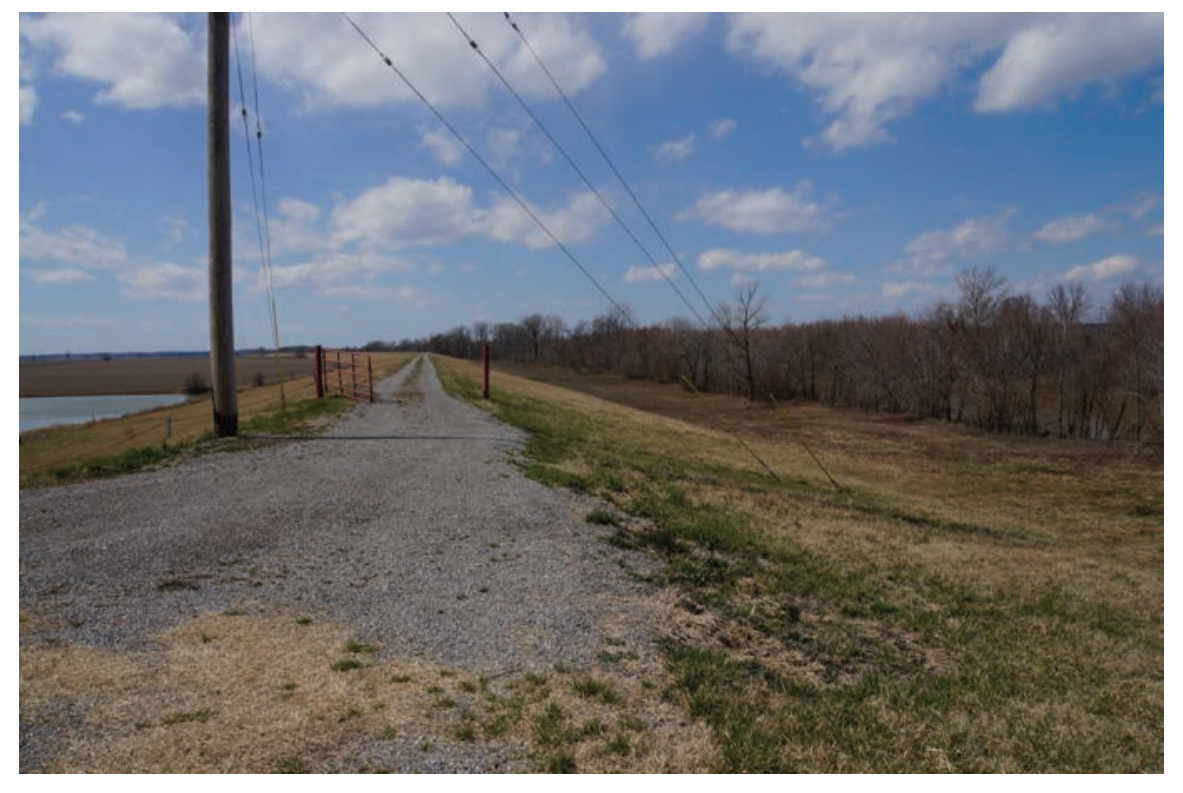

embankment so as to serve as a spillway if the maximum flood capacity was exceeded. While use of this spillway would flood 800 ha $(2,000 \mathrm{ac})$, it would protect the levee on the south side of the diversion channel from failing. The diversion channel and levee system was intended to be self-maintaining, relying primarily on gravity with no mechanical devices in the channel to control flow.

\section{ECONOMIC GROWTH AND DEVELOPMENT}

Three events contributed to the new drainage district's success and coincided with LRDD efforts to construct levees and drainage channels in southeast Missouri. First, railroads were built into the Big Swamp from Illinois to carry the timber out as a result of the 1905 construction of the Thebes railroad bridge (Olson and Morton 2014). The Thebes reinforcedconcrete railroad bridge allowed railroad lines to be constructed deep into the Big Swamp and enabled the extracted logs to be transported by railroad cars to eastern markets. The second event was the building of a lock and dam on the Mississippi River at Keokuk, Iowa, in 1913. The dam, fought by the timber interests, transformed the industry in the upper Midwest because it stopped log drives from coming down river. Timber companies, needing trans- portation to move timber from their hardwood forests, became sources of new revenue and enabled the railroad system to expand. Third, after construction of the Panama Canal ended in 1913, large numbers of skilled workers sought new jobs, and they found them in the earth-moving business of southeast Missouri (Blackwell 2007). Thousands of workers moved their families to Missouri and found livelihoods in the incredibly difficult and dangerous work of clearing, mostly by hand, the swamp of trees and stumps.

The Great Mississippi Flood of 1927 (Barry 1997) and the Great Depression from 1929 to 1935 made it impossible for the LRDD to make payments on construction funds. The Flood Control Act of 1928 authorized the US Army Corps of Engineers (USACE) to improve the Headwaters Diversion channel and mainline levee to protect against future Mississippi River flooding and levee breaching. This new partnership was a critical infusion of resources that helped the LRDD maintain the newly constructed systems of levees and channels protecting human settlements and agricultural lands. However, the district carried an outstanding debt of almost US\$7.6 million on the US\$11 million originally financed in 1913. Crop prices dropped so low that many crops went unharvested, and the timber business struggled to survive during the Depression. Many landowners defaulted on their mortgages and their US $\$ 10 \mathrm{ha}^{-1}$ (US $\$ 4 \mathrm{ac}^{-1}$ ) benefit tax assessment while land prices dropped to US\$37.50 ha $\mathrm{ha}^{-1}$ (US\$15 $\mathrm{ac}^{-1}$ ). In 1937 , after both the Depression and the flood of 1937, the LRDD received a US\$2.4 million loan from the Reconstruction Finance Corporation, a New Deal agency that provided assistance to businesses. Forty-three years after beginning construction, in April 1952, LRDD settled the bond debt and paid off the construction phase of the drainage system (LRDD 2007).

The Headwaters Diversion channel and levee system was built to expand agricultural lands and protect cropland from seasonal and extreme flood events. By 1937 much of the former Mississippi River valley southwest of Cape Girardeau, Missouri, was settled, and the alluvial bottomland soils became productive lands growing corn (Zea mays L.), grain sorghum, wheat, cotton, and rice. The creation of the diversion channel in 1915 increased the volume of water flowing into the Mississippi River and raised the high water marks on the river at the Cape Girardeau, Cairo, and New Madrid gages during major flood events. Prior to the construction of the floodwall and levee system between 1956 and 1964, Cape Girardeau flooding was a common occurrence (e.g., 1922, 1927, 1943, 1944, 1947, and 1951). The current levee system and floodwall (figure 7) was built by the USACE (Camillo 2012) at a cost of US $\$ 4$ million dollars and requires additional funds each year to maintain (Koenig 2012a, 2012b). It is 2,185 m $(7,210 \mathrm{ft})$ long, including a 1,212 m (4,000 ft) floodwall that can handle a $16.4 \mathrm{~m} \mathrm{(54}$ $\mathrm{ft})$ peak on the Cape Girardeau gage.

\section{MANAGING MISSISSIPPI RIVER FLOODS}

Subsequent Mississippi River floods have challenged the LRDD to be vigilant in maintaining levees and channels. The Mississippi River rose to record height again in 1973, threatening the Headwaters Diversion levee. The levee held, but the district discovered numerous weak spots and has in recent years invested considerable resources to assure long-term protection 
of the region (LRDD 2007). The LRDD levees constructed by the USACE were built to an elevation to safely pass a 500year flood event. In 2010, the USACE made their 5-year inspection of the LRDD levee system and certified that it met all requirements for the National Flood Insurance Levee Evaluation Report (LRDD 2012) of passing a 100 -year flood event. This accreditation means that landowners behind LRDD levees are not subject to purchasing mandatory flood insurance.

The Headwaters Diversion levee held during another great flood, that of 2011, which required the USACE to activate the New Madrid floodway to protect Cairo and downstream communities against uncontrolled breaching damage along the frontline levee of southeast Missouri. Record rainfall in March and April of 2011 occurred throughout the entire LRDD watershed, with the Headwaters Diversion subwatershed receiving more than $75 \mathrm{~cm}$ (30 in) of rainfall causing two district detention basins to overtop and their levees to crevasse (LRDD 2012). Postflood inspection of the Headwaters Diversion channel and levees on its south side uncovered 11 sites of erosion and bank caving in the West basin levee and damage to the channel levee where slow-velocity sand boils occurred (LLDD 2012). The USACE has addressed these weaknesses and is working on a redesign of the levee to prevent future sand boils.

Today, the $72 \mathrm{~km}$ (45 mile) long Headwaters Diversion channel diverts more than 288,000 ha $(720,000 \mathrm{ac})$ of upland (Francois Mountains and Ozark Plateau) runoff water directly into the Mississippi River. The LRDD has about 3,000 land owners and parcels varying from 0.20 to 20,000 ha (0.5 to 50,000 ac) in size. In 2012, these land owners paid over US $\$ 1.2$ million in benefit tax assessments for levee mowing, channel clearing and excavation, brush spraying, ditch mowing, and overall district operations (LRDD 2012).

The 1907 formation of the LRDD enabled the Big Swamp to be drained, cleared of trees, and cultivated. The region now has some of the most productive land in Missouri. The LRDD provided a social, economic, and physical infrastructure for southeast Missouri, offering economic benefits to timber and farming interests; making dry land for homes, towns, and industries; and incentivizing an extensive transportation system. Without the Headwaters Diversion channel and levee, thousands of hectares (acres) of agricultural bottomlands would not be protected from ordinary or floodwater runoff from the Castor and Whitewater rivers. The Cape Girardeau Regional Airport area site (figure 1) was often covered by $6 \mathrm{~m}$ $(20 \mathrm{ft})$ of water prior to the construction of the Headwaters Diversion. Before 1907 and the draining of the Big Swamp, Bloomfield Road, the only road going south from Cape Girardeau, followed the ridges. The railroad, bridge, and road infrastructure was central to the economic and social development of southeast Missouri.

The LRDD was one of the first drainage districts to be formed in the United States (Olson et al. 2011), and currently, in partnership with the USACE and Mississippi River and Tributaries Commission, the LRDD manages $1,536 \mathrm{~km}(960 \mathrm{mi})$ of ditches and $486 \mathrm{~km}$ (304 mi) of levees protecting over 480,000 ha (1.2 million ac) of land (Pracht and Banks 2002; Camillo 2012; Olson et al. 2016).The Headwaters Diversion is a critical component of this drainage network.
CONSEQUENCES OF THE LITTLE RIVER DRAINAGE DISTRICT DIVERSION ON MISSISSIPPI RIVER BOTTOMLANDS IN ILLINOIS, MISSOURI, AND KENTUCKY

Construction of levees, diversions, and floodways, and land use conversion from wetlands to agriculture for the last 200 years, have substantively altered the hydrologic cycle of the region. The Little River levee and LRDD Headwaters Diversion channel built in the 1910 s successfully permitted the drainage of the 800,000 ha (1.2 million ac) Big Swamp in the Bootheel of Missouri. However, it also had the unintended consequence of increasing the flow and peak of Mississippi River water south of Cape Girardeau through the Thebes gap and south to Helena, Arkansas, a distance of approximately 360 river miles. When the Ozark uplands and Francois Mountains experience above average rainfall for extended periods of time, the additional runoff transported by the diversion channel (approximately 270,000 ha-m y ${ }^{-1}$ [2 million ac- $\left.\mathrm{ft} \mathrm{yr}^{-1}\right]$ ) increases the chances of Mississippi River levee breaches south of Commerce, Missouri, and adds to the peak river height at the confluence of the Ohio and Mississippi rivers (Olson and Morton 2012).

\section{Figure 7}

The murals on the Cape Girardeau floodwall.

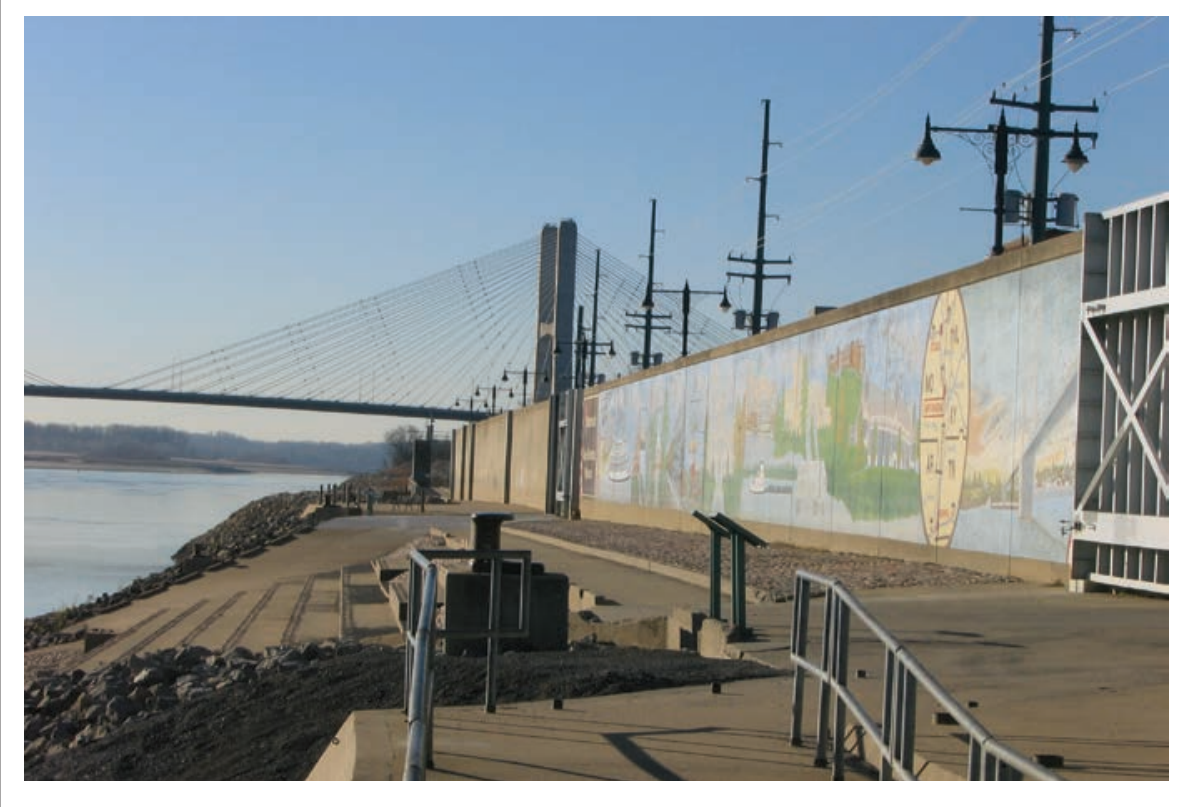


The increase in Mississippi River peak flow placed additional river pressure on levees and led to increased flooding, especially during the floods of 1927 , 1937, and 2011. The Kentucky, Illinois, and Missouri farmers' and land owners' response to the additional volume and height of the Mississippi River from the diversion channel valley and the prevention of the Mississippi River floodwaters from flowing into the ancient Mississippi River valley and Big Swamp was to build floodwalls and levees. Cape Girardeau, after 1915, experienced repeated flooding and built a floodwall to protect the city. The Great Flood of 1927 resulted in Cairo building a floodwall and strengthening levees and the creation of the Birds Point-New Madrid floodway. The Len Small (built in 1943)-Fayville (built in 1969) farmer levee in Illinois (Olson and Morton 2013), the Hickman levee in Kentucky, and the Commerce farmer levee in Missouri were also constructed and strengthened after the completion of the Headwaters Diversion. Over time, the Kentucky landowners were able to get the USACE to strengthen the mainline Hickman levee, which did not fail in either 1993 or 2011. However, the Len Small-Fayville levee failed in 1993, and both the Commerce farmer and Len Small-Fayville levees failed during the 2011 flood.

Climate scientists predict a continued pattern of extreme rainfall events in the upper Mississippi River region. This suggests that unexpected above average rainfall events in uplands and flood plains will continue to add to the high peak flows in the Mississippi River. There is a need for additional floodwater storage in the greater Ohio-Mississippi river confluence area. A regional effort on both sides of the Ohio and Mississippi rivers is needed to strategically identify floodplain areas that could provide temporary water storage and policy incentives for landowners of low-lying lands to profitably invest in crops and income alternatives.

\section{ACKNOWLEDGEMENTS}

Funding support comes from Regional Research Project No. 15-372 and in cooperation with North-
Central Regional Project No. NCERA-3 Soil Survey as well as the Director of the Illinois Office of Research; College of Agricultural, Consumer, and Environmental Sciences; University of Illinois; Urbana, Illinois. Open access was funded by National Great River Research and Education Center, Alton, Illinois. Additional funding for this research was provided by the Iowa Agriculture and Home Economics Experiment Station, College of Agriculture and Life Sciences at Iowa State University, Ames, Iowa, and in cooperation with North-Central Regional Project No.1190, Catalysts for Water Resource Protection and Restoration: Applied Social Science Research.

\section{REFERENCES}

Barry, J.M. 1997. Rising Tide: The Great Mississippi Flood of 1927 and How It Changed America. New York: Simon and Schuster.

Blackwell, S. 2007. A landscape transformation by the Little River Drainage District. Southeast Missourian. Nov. 4, 2007.

Burns, B.F. 1919. Board mattress for preventing scour in drainage channel. In Engineering and Contracting, eds. H.P. Gillette, Sir H. Davy, J Davy.Vol LII (September 10):299.

Camillo, C.A. 2012. Divine Providence: The 2011 Flood in Mississippi River and Tributaries Project. Vicksburg, MS: Mississippi River Commission.

Cremeens, D.L., R.G. Darmody, and S.E. George. 2005. Upper slop landforms and age of bedrock exposures in the Francois Mountains, Missouri: A comparison to relict periglacial features in the Appalachian Plateaus of West Virginia. Geomorphology 70(1-2):71-84, doi: 10/1016/j. geomorph2005.04.001.

Elephant Rocks State Park. 2014.Visitor center exhibit. Belleview, MO: Elephant Rocks State Park.

Engineering Record. 1914. The Little River Drainage improvements 70:8:204-206.

Joiner, J. 2010. Swamps to Cotton. Rural Missouri, Association of Missouri Electric Cooperatives. http://www.rootsweb.ancestry. com/ mostodd2/history/swampstocotton.htm.

Kochtitzky, O. 1931. Memoir. In The Story of a Busy Life (published in 1957). Cape Girardeau, MO Ramfre Press.

Koenig, R. 2012a. Corps balancing levee repairs on Missouri, Illinois sides of Mississippi. St. Louis Beacon. July 30, 2012.

Koenig, R. 2012b. Environmental groups battle farm, business interests over Bootheel levee project. St. Louis Beacon. Sept. 27, 2012.

LeMaitre, R.W., A. Streckeisen, B. Zanettin, M.J. LeBas, B. Bonin, and P. Bateman. 2002. Igneous
Rocks: A Classification and Glossary of Terms. Cambridge: Cambridge University Press

Lewis, K. 2012. Work on the Little River Drainage District. Semo News Service. Oct. 5, 2012 http://www.dddnews.com/story/1901027.html. LRDD (Little River Drainage District). 2007. Little River Drainage District of Southeast Missouri 100 Year Report (1907-2007). Cape Girardeau, MO: Little River Drainage District.

LRDD. 2012. 2012 Annual Report. December 2012. Cape Girardeau, MO: Little River Drainage District. LRDD Staff (Little River Drainage District Staff). 1909. Final report of Board of Engineers of Little River Drainage District of Missouri [Exhibit III]. Cape Girardeau, MO: Little River Drainage District.

McCord M.W. 2014. Castor River, Missouri. Southwest Paddler. http://southwestpaddler. com/docs/castor2.html.

Olson, K.R., and L.W. Morton. 2013. Impacts of 2011 Len Small levee breach on private and public Illinois lands. Journal of Soil and Water Conservation 68(4): 89A-95A. doi:10.2489/ jswc.68.4.89A.

Olson, K.R., and L.W. Morton. 2012. The effects of 2011 Ohio and Mississippi River Valley flooding on Cairo, Illinois. Journal of Soil and Water Conservation 68(4): 89A-95A. doi:10.2489/ jswc.67.2.42A.

Olson, K.R., and L.W. Morton. 2014. Dredging of the fracture bedrock lined Mississippi River channel at Thebes, Illinois. Journal of Soil and Water Conservation 69(2):31A-35A, doi:10.2489/ jswc.69.2.31A.

Olson, K.R., L.W. Morton, and D. Speidel. 2016. Little River Drainage District conversion of the Big Swamp to fertile agricultural land. Journal of Soil and Water Conservation 71(2): forthcoming. Olson, K.R., M. Reed, and L.W. Morton. 2011. Multifunctional Mississippi River leveed bottomlands and settling basins: Sny Island Levee Drainage District, Journal of Soil and Water Conservation 66(5):104A-110A, doi:10.2489/ jswc.66.4.104A.

Pracht, C., and J. Banks. 2002. The Little River Drainage District collection. Collection Building 21(1):10-12. 